\title{
Impacts of climate variability on growth and Variability of agricultural productivity: a review
}

\section{Impactos de la variabilidad climática en el crecimiento y la variabilidad de la productividad agrícola: una revisión}

\author{
Rekha Kumari, Shruti Kanga* \\ Centre for Climate Change and Water Research, Suresh Gyan Vihar University, Jaipur, India \\ *Author for correspondence; e-mail: shruti.kanga@mygyanvihar.com
}

\begin{abstract}
This paper has a comprehensive review of different research papers, reports, and articles associated with the impacts of climatic parameters' variability, mainly temperature and rainfall, on agricultural productivity and variability. Agriculture is the most vulnerable economic field to climate change. According to the most recent projections, the farmers' adaptation of farm development to climate change is imminent. The climate attributes that most directly impact agricultural production are expected to increase temperatures, evolving precipitation frequency, intensity, and growing photosynthesis $\mathrm{CO}_{2}$ levels. This paper analyses climate change economic costs in the last thirty years of Indian agricultural production and examines the impacts on policymakers and agricultural science. Results show that adaptive activities have a significant and beneficial effect on productivity; irrigation improvement has been the method with the highest impact on productivity. Empirical evidence indicates that climate change already exists and has a significant effect on agricultural production. To sustain their quality of living, farmers must adjust to the predicted impacts of climate change. Adapting agriculture to climate change requires both crop restructuring and improvements in agricultural practices. Climate change adaptation is necessary to maintain and encourage growth in agricultural productivity and empirical evidence for site-specific policymaking. This research, therefore, analyses the effect on the efficiency of adaptation to climate change. Empirical findings indicate the importance of transformation to farmers' productivity to climate change and enrich discussions on adopting adaptation measures.
\end{abstract}

Keywords: Agricultural Productivity, Crop Yield, Climate Change, Climate Variability. 
Sustainability, Agri, Food and Environmental Research, (ISSN: 0719-3726), 9(2), 2021: 311-328 http://dx.doi.org/10.7770/safer-VONO-art2244

\section{RESUMEN}

Este artículo tiene una revisión integral de diferentes trabajos de investigación, informes y artículos asociados con los impactos de la variabilidad de los parámetros climáticos, principalmente la temperatura y la lluvia, sobre la productividad y la variabilidad agrícola. La agricultura es el campo económico más vulnerable al cambio climático. Según las proyecciones más recientes, la adaptación de los agricultores del desarrollo agrícola al cambio climático es inminente. Se espera que los atributos climáticos que impactan más directamente en la producción agrícola aumenten las temperaturas, evolucionen la frecuencia e intensidad de la precipitación y aumenten los niveles de $\mathrm{CO}_{2}$ de la fotosíntesis. Este artículo analiza los costos económicos del cambio climático en los últimos treinta años de la producción agrícola de la India y examina los impactos sobre los responsables de la formulación de políticas y la ciencia agrícola. Los resultados muestran que las actividades de adaptación tienen un efecto significativo y beneficioso sobre la productividad; La mejora del riego ha sido el método con mayor impacto en la productividad. La evidencia empírica indica que el cambio climático ya existe y tiene un efecto significativo en la producción agrícola. Para mantener su calidad de vida, los agricultores deben adaptarse a los impactos previstos del cambio climático. La adaptación de la agricultura al cambio climático requiere tanto la reestructuración de cultivos como mejoras en las prácticas agrícolas. La adaptación al cambio climático es necesaria para mantener y fomentar el crecimiento de la productividad agrícola y la evidencia empírica para la formulación de políticas específicas del sitio. Esta investigación, por tanto, analiza el efecto sobre la eficiencia de la adaptación al cambio climático. Los hallazgos empíricos indican la importancia de la transformación de la productividad de los agricultores al cambio climático y enriquecen las discusiones sobre la adopción de medidas de adaptación.

Palabras clave: productividad agrícola, rendimiento de cultivos, cambio climático, variabilidad climática.

\section{INTRODUCTION}

India is in South Asia and has over 1.2 billion people, making it the second-most populous country globally. In the last four decades, the country has made tremendous progress in food production and availability. However, large numbers of people are still food insecure and malnourished. India covers several climate regions: wet, dry, or humid tropical south, but rugged alpine mountain ranges in the Himalayan north. Today India is in terms of agricultural production the second largest country in the world. Around 180 million hec- 
Sustainability, Agri, Food and Environmental Research, (ISSN: 0719-3726), 9(2), 2021: 311-328 http://dx.doi.org/10.7770/safer-V0N0-art2244

tares of land for agriculture, $60.5 \%$ of the total land area. The sector accounts for approximately $14 \%$ of the real GDP and hires over $50 \%$ of its workers. While agriculture is steadily decreasing in contribution to total GDP, agriculture is the largest industry in India and plays a significant role in its socio-economic growth. About 35 percent of India's whole agricultural land is irrigated, and the rainfall depends entirely on two-thirds of the grown land. The country's agricultural production system is more vulnerable to severe weather damage, contributing to increased water stress and insufficient irrigation supplies. The increase of average temperatures, changes in rainfall patterns, rising frequency of extreme weather events such as severe droughts and floods, and changes in farming seasons in various agro-ecological areas of India are among the most critical factors in agricultural productivity. Long drought spells during Kharif and higher temperatures and heavy rainfall during the rabi season have caused a great deal of distress for farming communities in various states.

The Intergovernmental Panel on Climate Change (IPCC, 2007) reveals it discloses the cause of Climate change or any changes in climate over the years, environmental and ecological deviations due to anthropogenic actions or by any natural disaster. Climate change is due to the rise in the level of greenhouse gasses in the atmosphere; accordingly, the effects of greenhouse gasses give rise to temperature, air pollutions, etc. (Matthew et al. 2015; Yu et al. 2018). Climate change and agriculture are associated worldwide and regional (Alexandrov and Hoogenboom 2000; Adejuwon 2005). Eventually, this interconnection connection between climate change and agriculture impacts agricultural productivity and food grain production worldwide and regionally through ever-increasing climate change (Kang et al. 2009).

Another main agricultural challenge is increasing agricultural yield and decreasing agricultural greenhouse gas (Headey et al. 2010). With the increase in the population globally, the agricultural system needs to raise its production capacity (Isik and Devadoss 2006; Khordadi et al. 2019). These subsequent pusses the excessive use of pesticides and fertilizers, and other resources to increase agricultural greenhouse gas emissions (Molua 2009; Yu et al. 2018). It is an utter need to quantify sustainable agriculture practice to increase agricultural production without harming environmental stability (Marshall et al. 2015; Ochieng et al. 2017).

The assessments of the effects of climate change on agricultural change and land use patterns are based on climate change evaluations' impact on agriculture's spatial design (Rowan et al. 2011; Banerjee et al. 2014; Asseng et al. 2015). Worldwide, individual crop production declines by $10-38 \%$ under these climate change scenarios, with considerable uncertainty in spatial patterns determined by climate estimates' fate and impact models' choice (Chen et al. 2004a; Babushkina et al. 2018a). Uncertainty about the effects of 
Sustainability, Agri, Food and Environmental Research, (ISSN: 0719-3726), 9(2), 2021: 311-328 http://dx.doi.org/10.7770/safer-V0NO-art2244

climate on plant productivity must be considered in economic assessments of climate change (Kang et al. 2014; Rolim et al. 2017).

The climate variability and its effects and outcomes on an agriculture growth trend and variability will be further dangerous for the nations with greater initial temperature and the areas with degraded lands even small or large (Rowhani et al. 2011; Loua et al. 2019). The effect will be exponential for the underdeveloped and developing countries with inadequate adaption capacity (Salim and Islam 2010; Müller and Robertson 2014). On the contrary, some studies stated that current agricultural practice and its associated actions are the leading cause of greenhouse gasses that produces poorer climate condition (Cai et al. 2015; Iizumi and Ramankutty 2016). Several investigation reports approximated that the change in rainfall, temperature and uncertain happening of weather conditions are predicted to diminish agricultural production in several countries, regions of the underdeveloped and developing world, mostly Africa and parts of Asia (Gbetibouo et al. 2010; Joshi et al. 2011; Egbebiyi et al. 2019).

The abruptly changing climate impacts the agricultural system throughout the world, so as India (Praveen and Sharma 2019). The occurrence of extreme events, e.g., floods, droughts, heatwaves, and dry days, had increased in India over the recent past, resulting in decreased agricultural productivity (Goyal and Kumar 2013). The production of wheat in India's northern parts will reduce drastically due to increasing temperature and heat haves (Suman et al. 2018). Also, in the Indo-Gangetic regions, almost $50 \%$ of the land will not be suitable for wheat cultivation by 2050 due to heat haves and raised temperature (Dinar et al. 2007; Aryal et al. 2018). The need is to increase the sustainable and climateresilient agricultural practices to adopt the climatic uncertainties and reduce climate change and uphold the agricultural requirements (Kumar et al. 2004).

For India, state-wise statistical analysis, it has been established that the drought and extreme rainfall had affected the rice yield adversely, mainly in the rain-field regions in the past decades (Kumar et al. 2004; Mall et al. 2006). It was noticed that the droughts had larger effects than extreme rainfall. Although due to the enhanced farming and use of fertilizer and pesticides in the past decades, there had been a sufficient increase in agricultural productivity (Kumar et al. 2004; Jain 2018). The pattern of pesticide use in India is different from that of the rest of the world. About $76 \%$ of India's pesticide is an insecticide, compared to $44 \%$ globally (Mathur, 1999). Herbicides and fungicides are also less heavy to use. The most considerable use of pesticides in India is cotton (45 percent), followed by paddy and wheat. The main advantages are the benefits of pesticides - the immediate gains that their use anticipates. For example, killing caterpillars on the crop benefits most from higher yields and better quality of chocolate. The three main effects contribute to 26 main advantages, ranging from leisure site safety to life-saving. The secondary benefits result from the primary advantages are less immediate or less evident. 
They can be subtle, less intuitive, or long-term. It is also harder to assess cause and effect for secondary benefits, but they can justify pesticides. For example, higher cold yields may lead to increased revenues for education and medical care for children contributing to a healthier, better-educated population. Several secondary benefits, from suitable people to preserved biodiversity, are listed.

At first glance, there are good reasons to expect that the costs of climate change will not be borne equally by developing countries in rural areas by developing countries (Rani et al. 2011; Jacoby et al. 2015). Finally, ownership of the most climate-sensitive property, the agricultural land, generally focuses on the least impoverished rural population. If the decline in agricultural productivity is global, climate change will increase world food prices, which, given the openness of trade, can benefit farmers (Shruthi et al. 2017; Kakumanu et al. 2019).

The use of pesticides in forestry, public health and domestic industries, and agriculture, which largely depends on the Indian economy, has brought tremendous benefits. Foodgrain production, which amounted to only 50 million tonnes in 1948-49, increased almost four-fold from the approximate 169 million hectares of the permanently cultivated field to 198 million tonnes by the end of 1996-97. This was done using high-yield seeds, advanced irrigation technologies, and agrochemicals. Improved efficiency was attributed to various factors, including fertilizer use, improved varieties, and machinery use. Pesticides have become an essential part of the operation by reducing weed, disease, and insect pest losses, reducing harvest volumes. Most pesticides are often photochemically transformed in the atmosphere to create metabolites relatively nontoxic to humans and the environment.

The main factors of climate change affecting agricultural productivity are rising temperature, extreme rainfall, greenhouse gases, mainly atmospheric carbon dioxide content, and sea-level rise (Rawat 2012). The agricultural productivity and security of food are the most threatened by Climate change in the twenty-first century, mostly for the poor of developing nations and in the coastal regions based countries based on agriculture, mountainous agriculture-based countries (Anjum and Madhulika 2018). With the growing population, the agricultural productivity required increased more (Panda and Sahu 2019). The impacts of extreme dry days and excessive rainfall with droughts and floods caused by climate change have to be met to meet future requirements (Patel et al., 2019).

The maximum amount of water is used in the agriculture sector regionally as well as globally. Climate change initially affects water resource availability, so as the agricultural productivity is getting affected afterward, the other interdependent industries that rely upon agriculture are subsequently affected (Das et al. 2009; Nimbrayan et al. 2019; Patel et al. 2019). For potential assessments and projections, the global combined effects of 
Sustainability, Agri, Food and Environmental Research, (ISSN: 0719-3726), 9(2), 2021: 311-328 http://dx.doi.org/10.7770/safer-V0NO-art2244

climate change on waters, agriculture, ecosystem, ecology, and other interconnected sectors should be considered (Dinar et al. 2007; Kanga et al. 2017).

\section{MATERIAL AND METHODS}

India accounts for $16 \%$ of the world's population but just $4 \%$ of global water supplies. Agriculture is directly dependent on the climate since crop growth's key factors are temperature, sunlight, and water. While certain aspects of climate change such as longer growing seasons and warmer temperatures will bring advantages to plant growth and development, there will also be several adverse repercussions as water is less available and severe weather conditions become more common. In India, the rising population is a significant problem, and water availability needs to be understood to increase population growth. Rainfall in India has a direct relationship with the Indian and Arab Monsoons. A more warm climate would speed up the hydrology cycle, shift precipitation, magnitude, and runoff timing. Warm air retains more moisture, which contributes to an increase in surface moisture evaporation. Thus, climate change will affect soil moisture, groundwater recharge, flooding or drought frequency, and soil water level in different areas. Climate change effects would have an impact on the water cycle.

Moreover, the rise in sea levels would increase the risk of permanent or seasonal infiltration of salt into groundwater and rivers, affecting water quality and future domestic, agricultural, and industrial uses. The impact of climate change on agriculture will be multiple. Higher temperatures and changing precipitation trends would have a significant effect on crop production patterns. The increased carbon dioxide in the environment would also impact agricultural production. All these reforms will make the landless and the poor more vulnerable. Several recent analyses have suggested that the higher temperatures predicted in the coming years would impact agriculture in the lower latitudes of the planet, where most of the worlds poor live disproportionately.

Predictions of Climate Change at the India Level

The predictions of upcoming climate change trends are constructed on a computer-based model that will integrate various significant aspects and progressions of the atmosphere and the oceans and the probable progression in greenhouse gases from socio-economic situations for the upcoming periods. The IPCC had examined the outcomes of numerous models, and based on those indications, the projections by 2100 as follows.

1. The world-wide mean surface temperature, i.e., surface air temperature change, will rise from 1.1 to $6.4^{\circ} \mathrm{C}$. 
2. The mean sea level is supposed to increase by $18 \mathrm{~cm}$ to $59 \mathrm{~cm}$, and the oceans' water will be more acidic.

3. The probability of extreme heat waves and heavy rainfall will increase, which will be more regular.

4. It was assessed that the rainfall would increase at the high latitudes and high altitudes, and a decrease in most of the subtropical region.

The mean surface temperature in India had increased by $0.4^{\circ} \mathrm{C}$ in the past 100 years. A warming trend was observed in the western coast, central and northern-eastern parts of India and cooling effects had been noticed in the northwestern and southern parts of India. Over the past 100 years, there had not been much change in the monsoon rainfall trends nationally in totality, but the regional monsoon rainfall had shown a significant variability. On the western coast, northern parts of Andhra Pradesh and northwestern parts of India, increasing trends of $10 \%$ to $12 \%$ from average rainfall had been observed during the last 100 years whereas, in the eastern part of Madhya Pradesh, north-eastern parts of India, and some parts of Gujarat and Kerala, a decreasing trends of $6 \%$ to $8 \%$ from the average rainfall had been observed during the last 100 years (Auffhammer et al. 2011). From the analysis of coastal tide gauge data in the Indian Ocean of more than 40 years, the scientists projected a rise of $1.06 \mathrm{~mm}$ to $1.75 \mathrm{~mm}$ rise in mean sea level per year. The sea-level rise rate is relatable with the 1 to $2 \mathrm{~mm}$ global sea-level height per year approximated by IPCC. The intensity of monsoon rainfall is projected to increase by $10 \%$ by 2100 . The research and forecast carried out by the Indian Institute of Tropical Meteorology (IITM), Pune, had projected the yearly mean surface temperature would increase by 3 to $5^{\circ} \mathrm{C}$ by the end of 2100 . The study also expected that the increase would occur mostly in the northern part of India.

From 1891 to 2009, India endured 23 significant droughts, and the frequency of droughts is rising. Climate change poses a considerable challenge to agriculture and food safety. Water is India's most important agricultural input, with no irrigation facility in $55 \%$ of the cultivated areas. We are actually in a position to protect food supplies under these various conditions. All climate models forecast that more severe weather conditions will occur, with more droughts, heavy precipitation, and storms in agricultural production regions. Such extreme weather events can affect the location and the time of diseases, thereby posing serious risks and possible crop failure. Climate change is an additional burden in developing countries such as India, given that ecological and socio-economic structures already face rapid population, industrialization, and economic development. India's climate could warmer under increased carbon dioxide in the atmosphere. To meet this rising population's food demand, farmers in the country must produce 50 percent more grain by 2020 . The overall gross irrigated surface area has more than quadrupled 
between 1950-51 and 2011-2012 from 22,6 million ha to 99,1 million ha. Though agriculture accounts for $14 \%$ of India's GDP, $64 \%$ of the population are dependent on agriculture for livelihood. Over the years, water demand has risen due to urbanization, population growth, rapid industrialization, and other development initiatives. Changes in crop and land-use patterns, overuse of groundwater, irrigation, and drainage changes have also changed the hydrological cycle in many of India's climate regions and river basins. The most significant factor in agricultural production is the availability of water. Water quality and quantity in most parts of India are severe constraints on agriculture.

Agriculture must adapt by tapping water supplies and designing better water management methods to adjust climatic conditions. Around the same time, technologies and policies need to be developed and enforced to minimize greenhouse gas emissions. The assessment of the availability of water supplies is therefore of future national requirements and the anticipated climate change effects, and their variability is crucial for national and regional long-term sustainable development strategy

Agriculture is an economic field that is important to climate change research. It is located at the interface between ecosystems and society and is heavily influenced by environmental conditions changes. Food prices, food security, land use, and rising vulnerability for crop managers are affected by climate change. The magnitude of climate change's effect depends on the degree of farm adaptation, farmers' investment decisions, and policy decisions, and they are connected. Therefore, it is essential to consider the impact of limitations on natural resources on agriculture to improve climate change resilience at the farm level.

On the other hand, as natural resources are increasingly restricted for food production, crop productivity is crucial to promoting agriculture growth and prosperity. To improve these restrictions, farmers have been adapting their practice for decades to meet climate variability; however, climate change now poses a rising threat to their livelihoods, including regular and intense weather extremes such as droughts, floods, and frost. In this research, we study whether adaptive practices will increase productivity based on India's annual crops in various agricultural systems. Farm systems' effective adaptation practices include soil conservation, effective water use, planting trees, change in planting dates, and improved varieties. Farmers who have become more knowledgeable and better prepared for climate change are expected to use their energy more efficiently and cope with any adversities. This study offers useful knowledge for agricultural policy design as proof of the effects of alternative climate change adaptation strategies. Also, the farmers and farming systems' characteristics are related to productivity to inform agricultural policy. 
Sustainability, Agri, Food and Environmental Research, (ISSN: 0719-3726), 9(2), 2021: 311-328 http://dx.doi.org/10.7770/safer-V0NO-art2244

\section{Climate Change in Agriculture}

Climate change and weather is directly impacting agricultural production. Possible variations in rainfall, temperature, and $\mathrm{CO}^{2}$ concentration level are estimated to affect crop growth and yield expressively. The global influence of climate change on crop yield is restrained from being small to medium with effective adaptation and suitable irrigation practices (IPCC 2006). Worldwide agricultural productions may increase due to the doubling up of $\mathrm{CO}^{2}$ fertilization outcome. The agrarian shows will also be affected indirectly by climate changes causing the impact on the available water resources. Ultimately, India had even begun to experience seasonal deviation of temperature more by experiencing warmer winters and summers. From 1891 to 2009, India had experienced 23 massive droughts, and the regularity of droughts occurrence is rising. These Climate change tendencies are a significant risk to agricultural productions and their security. Water resources are the utmost dangerous agricultural input in India that needs to be taken care of, as $55 \%$ of the overall cultivated areas do not have proper irrigation facilities.

Agriculture production has been affected by various factors; the climatic factor is one of the most important and influencing factors. The increasing trend of temperature in India in the previous 100 years, from 1901 to 2007 had been Due to climate change, and agricultural production will decay by 4.5 - $9 \%$ shortly from 2010 to 2030 and by $25 \%$ in the long-run from 2070 to 2099 in the absence of farmers' variation.

Studies carried out by the Indian Agricultural Research Institute (IARI) and other researchers predicted a more considerable loss in the Rabi crops; for each $1^{\circ} \mathrm{C}$ increase in temperature, the productivity of wheat would decrease by 4- 5 Million Tonnes. Hence, a little change in temperature and rainfall will substantially affect the quality and the number of crops, grains, fruits, vegetables, etc.

According to IPCC 2006; 2001 the yield of rice and wheat possibly will decrease with climate change. The vulnerability of agricultural productions to climate change is also affected by the system of crop production, flood, and droughts, the adaption of farmers towards modern farming tools and techniques. For a $2^{\circ} \mathrm{C}$ to $3.5^{\circ} \mathrm{C}$ rises in temperature, the projected loss in the net revenue at ground level will differ from $9 \%$ to $25 \%$. The researchers also projected that for a $2^{\circ} \mathrm{C}$ increase in mean yearly temperature and a $7 \%$ increase in mean annual rainfall, the net revenue would decrease by $12.3 \%$ for the entire country. Gujarat, Karnataka, and Maharashtra will have maximum negative impacts. Punjab, Haryana, and Uttar Pradesh will have moderately adverse effects. Andhra Pradesh, Odisha, and West Bengal will positively impact productivity due to the increasing temperature.

Trend, Growth, and Variability of Agricultural Productivity 
A climatically driven investigation on yield variability of major crops in Khakassia, South Siberia, considered wheat, barley, and oats of spring and compared the northern, central, and southern zone. Multifactor linear regression analysis had been used for the variability analysis of the yield of crops. They concluded the possibility of a yield decrease in the product at least by $2-11 \%$ in the next decade because of the increasing temperature in the region (Babushkina et al. 2018, b).

The instability of crop area is least in the green revolution. The growth trend was decreasing in the pre-green process in Haryana and India. The production in Haryana had decreasing trends during the green course. The yield growth rate had been increasing in India and Haryana, (Nimbrayan et al. 2019). The crop area, production, and productivity of rice, wheat, and maize from 1990- 91 to 2012- 13 in India, compound to annual growth rate, and the coefficient of variance were used to see the period's trend pattern and instability. They concluded from the analysis that rice and wheat, the crop area, production, and productivity had increased, and the growth trends during the period had also increased. Mainly maize showed an increase in crop area, display, and yield since 2000 due to its high demand for industrial usage (Handral et al. 2017).

The model had been developed using 30 years of data from 1985- 2015 for groundnuts, paddy, and maize of Kharif season and wheat and mustard of rabi season. The model results showed up to $90 \%$ variation in the yield of groundnuts, $93 \%$ variation in the product of paddy, up to $87 \%$ variation in maize yield, up to $90 \%$ variation in the development of wheat and mustard. The model predicted the product with less than $10 \%$ deviation; conclude that this model can be used for yield forecasting (Yadav et al. 2018).

The yield of bajra, jowar, moth, urad, moong, seasame, cotton, and guar had high growth and instability. The productivity data of 20 years from 1995- 96 to 2014- 15 for almost all the crops; the yield of arhar had low growth and high instability. The Paddy product, soybean, gram, cumin, and the chili had low growth and instability. Finally, the yield of maize, wheat, barley groundnut, rapeseed \& mustard, linseed, castor, sugarcane, and garlic had high growth and low instability. The product of coriander and fenugreek had negative growth and intense instability (Suman et al. 2018). The crop area, production, and yield for sugarcane in Uttar Pradesh as Uttar Pradesh are the top sugarcane producing state. They used compound growth rate analysis for the time series data of 1950-2015. The study revealed that there had been an increase in the crop area, production, and yield of sugarcane during the last 65 years. The crop area had increased by $2.25 \%$, and sugarcane had risen by $1.96 \%$ during this period (Rai and Arti 2017).

The trends of crop area, production, and the Bengal gram's productivity in Andhra Pradesh from 1987 to 2007, the movements had been projected by the semi-log trend equation, and groundnut component growth analysis model had been used. They found that the trend of crop area, production, and productivity had increased significantly during 
Sustainability, Agri, Food and Environmental Research, (ISSN: 0719-3726), 9(2), 2021: 311-328 http://dx.doi.org/10.7770/safer-V0N0-art2244

this period. The analysis also showed that the output had changed because of the change in the area (Sitarambabu et al., 2014).

Impact of Temperature and Rainfall Variability on Agricultural Productivity

A climate change research by the Ricardian method in Cameroon, which a $7 \%$ decline in rainfall would cause net profits from crops to decrease US $\$ 2.86$ billion, and a $14 \%$ decline in rainfall, would generate net profits from crops to reduce US $\$ 3.48$ billion. Increases in precipitation would have the opposite effect on net revenues. For a $2.5^{\circ} \mathrm{C}$ warming, net profits would decrease by US $\$ 0.79$ billion, and a $5{ }^{\circ} \mathrm{C}$ warming would cause net profits to fall US $\$ 1.94$ billion (Molua 2009). Empirical models and analysis had done the effects of the projected climate change on agriculture. The results concluded that the average yields of the crop would be slightly influenced by climate change. Still, there will considerably decrease the variance and covariance for most of the crops considered (Isik and Devadoss 2006).

Year-wise yield variability had been computed from the maximum likelihood panel data of the crops. The results specified that the temperature and precipitation are directly proportional to the yield and variability for sorghum, but for corn, the effects were opposite (Chen et al. 2004b). In the yield response regression model to assess the climate change impact on 60 crops, results showed that the temperature and precipitation had a significant but inconsistent influence on crop yield (Chang 2002). The rainfall and temperature data from 1978- 2008 were analyzed using the regression model and yield data for the crops. The growth rate of crop yield for all the produce was positive. They found that the temperature trend had increased by $0.7^{\circ} \mathrm{C}$, but the rainfall had not changed considerably (Joshi et al. 2011).

Climate change remains connected with agriculture, and its impacts are currently seen throughout the globe. There have been strong relationships and dependency on agriculture in underdeveloped and developing countries of Africa and Asia. A large number of populations are dependent on the livelihood and employment of agricultural practices in these countries. All the farming practices are mostly reliant on the hanging on natural climatic situations in these countries. The developing and underdeveloped countries will impact most due to climate change and its effects on agricultural productivity and food security. Climate change creates interruption for improving the condition of any state or region. Hence, it is essential to spread awareness, modern tools, and farming practices for a reliable and sustainable environment. The most damaging impact of climate change will be on the farmers and the workers associated with the agriculture and food sector in lowincome countries. Thus, appropriate mitigation and adaptation implementing activities must be comprehensively made in practice used in this field. There are numerous convections and global contracts considering climate change, agriculture, and food security to create extensive awareness globally. 
The findings of the current study indicate that climate change is already taking place and the adaptation of Greek agriculture is thus of utmost importance. The degree to which climate change adapts is based on the seriousness and ability to mitigate negative impacts through funding from institutes for agricultural research, agricultural expansion programmes, education, farmers' networks as well as national and European policies. The adaptation efforts would differentiate between regions in terms of their rates of growth and living standards. Policy makers should encourage policies that can improve land use and crops as well as crop techniques. Sustainable development should also be taken into account in these policies.

Moreover, India's economic growth would significantly affect farmers' capacity to benefit from additional sources of revenue through the diversity of the rural sector "more crops per drop" rainwater collection, aquifer recharge, reactivation of water bodies, and conservation technology should be a priority. The central government has tried in the last ten years to resolve the problem utilizing a variety of initiatives, such as subsidies for micro-irrigation, the national watershed creation of rain-fed zones and the artificial recharge to groundwater by dug pools in hard-rock areas, as well as a program to increase rural water supply in the catchment area The results of the economic climate change projections generally suggest that the global climate change impact on farming is minimal. However, the significant financial loss will occur at the regional level, especially in India. As adaptation is slow, most estimates say that viable farm companies will adapt faster with the right investment by changing crops and cultivation practices.

\section{Conclusion}

Agriculture is generally the primary sector that depends mostly on climate change. The choice of the optimally grown crops and the selection of optimum planting and harvest times depend directly on each region's prevailing weather conditions. This means that the impending climate change due to greenhouse gas increases would directly impact agricultural production and productivity and, therefore, on farmers' incomes. The results of economic climate change estimate generally conclude that the global impact of climate change on agriculture is small. However, the significant economic damage will occur at the regional level, particularly in countries like India. Given the slow pace of adaptation, most estimates suggest that viable farming companies can adapt more quickly with the right investments by changing their cultivation and cultivation practices. This study shows that climate change is already taking place, and thus the adaptation of Indian agriculture is essential. The degree of adaptation depends on the seriousness of the climate change and the ability, through aid from institutes for agricultural research, agricultural extension services, education, farmers' networks, and national and European policies, to mitigate negative consequences. Adaptation initiatives can distinguish between regions in terms of their rates 
of growth and living standards. Climate change has a significant impact on the availability of various resources on the earth, mostly water that supports life on the planet. Biosphere transitions, biodiversity, and natural resources have a detrimental effect on human health and quality of life.

Throughout the 21st century, India will experience global warming. India would also undergo more seasonal temperature variations with more temperatures during winter than summers. In recent years, the longevity of the heat waves throughout India has increased with warmer night temperatures and hotter days, and that trend is expected to continue. The average temperature change is estimated to range from $2.33^{\circ} \mathrm{C}$ to $4.78^{\circ} \mathrm{C}$, with $\mathrm{CO} 2$ doubling. Those heatwaves will lead to increased variability in summer monsoon precipitation, resulting in dramatic impacts on the Indian agriculture sector. Climate models expect a progressive increase in the concentration and temperature of carbon dioxide ( $\mathrm{CO} 2)$ worldwide. However, these models are not entirely reliable to forecast potential changes in local weather conditions. In conjunction with local plant varieties, cultivating systems, and soil conditions, local weather conditions, such as rain, temperature, sunshine, and wind, can increase food production as long as plant disease can be managed. Policymakers should promote actions to help change the use of soil and crops and crop techniques. Furthermore, Indian economic development will significantly impact farmers' ability to benefit from additional income sources through the rural sector's diversity. Finally, policymakers should consider the importance of sustainable agricultural development through its three pillars: economic development, conservation of the environment, and social equity.

\section{ACKNOWLEDGMENT}

Rekha Kumari (Research Scholar) performing the research work Dr. Shruti Kanga (Associate Professor) and Dr. Suraj Kumar Singh have guided research work. The authors are grateful to the Centre for Climate Change and Water Research of Suresh Gyan Vihar University for providing infrastructural facilities.

\section{REFERENCES}

Adejuwon J. 2005. Assessing the suitability of the epic crop model for use in the study of impacts of climate variability and climate change in West Africa. Singap J Trop Geogr. 26(1):44-60. doi:10.1111/j.0129-7619.2005.00203.x.

Alexandrov VA, Hoogenboom G. 2000. The impact of climate variability and change on crop yield in Bulgaria. Agric For Meteorol. 104(4):315-327. doi:10.1016/S01681923(00)00166-0. 
Anjum S, Madhulika M. 2018. Growth and instability analysis in Indian agriculture. Int J Multidiscip Res Dev. 5(11):119-125.

Aryal JP, Rahut DB, Maharjan S, Erenstein O. 2018. Factors affecting the adoption of multiple climate-smart agricultural practices in the Indo-Gangetic Plains of India. Nat Resour Forum. 42(3):141-158. doi:10.1111/1477-8947.12152.

Asseng S, Ewert F, Martre P, Rötter RP, Lobell DB, Cammarano D, Kimball BA, Ottman MJ, Wall GW, White JW, et al. 2015. Rising temperatures reduce global wheat production. Nat Clim Change. 5(2):143-147. doi:10.1038/nclimate2470.

Auffhammer M, Ramanathan V, Vincent JR. 2011. Climate change, the monsoon, and rice yield in India. Clim Change. 111(2):411-424. doi:10.1007/s10584-011-0208-4.

Banerjee S, Banerjee P, Mukhopadhyay A. 2014. Implications of global warming on changing trends in crop productivity - A Review. Int Lett Nat Sci. 11:16-29. doi:10.18052/www.scipress.com/ILNS.11.16.

Babushkina EA, Belokopytova LV, Zhirnova DF, Shah SK, Kostyakova TV. 2018a. Climatically driven yield variability of major crops in Khakassia (South Siberia). Int J Biometeorol. 62(6):939-948. doi:10.1007/s00484-017-1496-9.

Babushkina EA, Belokopytova LV, Zhirnova DF, Shah SK, Kostyakova TV. 2018b. Climatically driven yield variability of major crops in Khakassia (South Siberia). Int J Biometeorol. 62(6):939-948. doi:10.1007/s00484-017-1496-9.

Cai X, Zhang X, Noël PH, Shafiee-Jood M. 2015. Impacts of climate change on agricultural water management: A Review. Wiley Interdiscip Rev Water. 2(5):439-455. doi: $10.1002 /$ wat2.1089.

Chang C-C. 2002. The potential impact of climate change on Taiwan's agriculture. Agric Econ.(27):51-64.

Chen C-C, McCarl BA, Schimmelpfennig DE. 2004a. Yield Variability as Influenced by Climate: A Statistical Investigation. Clim Change. 66(1/2):239-261. doi:10.1023/B:CLIM.0000043159.33816.e5.

Chen C-C, McCarl BA, Schimmelpfennig DE. 2004b. Yield Variability as Influenced by Climate: A Statistical Investigation. Clim Change. 66(1/2):239-261. doi:10.1023/B:CLIM.0000043159.33816.e5.

Das A, Senapati M, John J. 2009. Impact of Agricultural Credit on Agriculture Production: An Empirical Analysis in India. Reserve Bank India Occas Pap. 30(2):75-107.

Dinar A, Mendelsohn R, Evenson R, Parikh J, Sanghi A, Kumar K, McKinsey J, Lonergan S. 2007. Measuring the Impact of Climate Change on Indian Agriculture. The World Bank (World Bank Technical Papers). http://elibrary.worldbank.org/doi/book/10.1596/0-8213-4192-8.

Egbebiyi TS, Lennard C, Crespo O, Mukwenha P, Lawal S, Quagraine K. 2019. Assessing Future Spatio-Temporal Changes in Crop Suitability and Planting Season over West 
Sustainability, Agri, Food and Environmental Research, (ISSN: 0719-3726), 9(2), 2021: 311-328 http://dx.doi.org/10.7770/safer-V0N0-art2244

Africa: Using the Concept of Crop-Climate Departure. Climate. 7(9):102. doi:10.3390/cli7090102.

Garde YA, Shukla AK, Singh S. 2012. Pre-harvest forecasting of rice yield using weather indices in Pantnagar (Uttarakhand). Int J Agric Stat Sci. 8(1):233-241.

Gbetibouo GA, Ringler C, Hassan R. 2010. Vulnerability of the South African farming sector to climate change and variability: An indicator approach. Nat Resour Forum. 34(3):175-187. doi:10.1111/j.1477-8947.2010.01302.x.

Goyal AK, Kumar DS. 2013. Agricultural Production Trends and Cropping Pattern in Uttar Pradesh: An Overview. 2(2):7.

Handral AR, Singh A, Singh DR, Suresh A, Jha GK. 2017. Scenario of changing dynamics in production and productivity of major cereals in India. Indian J Agric Sci. 87(10):1371-1376.

Headey D, Alauddin M, Rao DSP. 2010. Explaining agricultural productivity growth: an international perspective. Agric Econ. 41(1):1-14. doi:10.1111/j.15740862.2009.00420.x.

Iizumi T, Ramankutty N. 2016. Changes in yield variability of major crops for 1981-2010 explained by climate change. Environ Res Lett. 11(3):034003. doi:10.1088/17489326/11/3/034003.

Isik M, Devadoss S. 2006. An analysis of the impact of climate change on crop yields and yield variability. Appl Econ. 38(7):835-844. doi:10.1080/00036840500193682.

Jacoby HG, Rabassa M, Skoufias E. 2015. Distributional Implications of Climate Change in Rural India: A General Equilibrium Approach. Am J Agric Econ. 97(4):1135-1156. doi:10.1093/ajae/aau084.

Jain A. 2018. Analysis of Growth and Instability in Area, Production, Yield and Price of Rice in India. :21.

Joshi NP, Maharjan KL, Luni P. 2011. Effect of Climate Variables on Yield of Major FoodCrops in Nepal: A Time-Series Analysis. Clim Change Agric Rural Livelihoods Dev Ctries. 1:19-26. doi:10.1007/978-4-431-54343-5_9.

Kakumanu KR, Kaluvai YR, Balasubramanian M, Nagothu US, Kotapati GR, Karanam S. 2019. Adaptation to climate change: impact of capacity building, India: adaptation to climate change. Irrig Drain. 68(1):50-58. doi:10.1002/ird.2275.

Kang Y, Khan S, Ma X. 2009. Climate change impacts on crop yield, crop water productivity and food security - A review. Prog Nat Sci. 19(12):1665-1674. doi: 10.1016/j.pnsc.2009.08.001.

Kang Y, Ma X, Khan S. 2014. Predicting climate change impacts on maize crop productivity and water use efficiency in the loess plateau. Irrig Drain. 63(3):394-404. doi:10.1002/ird.1799. 
Sustainability, Agri, Food and Environmental Research, (ISSN: 0719-3726), 9(2), 2021: 311-328 http://dx.doi.org/10.7770/safer-V0N0-art2244

Kanga S, Kumar S, Singh SK. 2017. Climate induced variation in forest fire using Remote Sensing and GIS in Bilaspur District of Himachal Pradesh. Int J Eng Comput Sci. 6(6):695-702. doi:DOI: 10.18535/ijecs/v6i6.23.

Khordadi MJ, Olesen JE, Alizadeh A, Nassiri Mahallati M, Ansari H, Sanaeinejad H. 2019. Climate change impacts and adaptation for crop management of winter wheat and maize in the semi-arid region of iran. Irrig Drain. 68(5):841-856. doi:10.1002/ird.2373.

Kumar KK, Rupa Kumar K, Ashrit RG, Deshpande NR, Hansen JW. 2004. Climate impacts on Indian agriculture. Int J Climatol. 24(11):1375-1393. doi:10.1002/joc.1081.

Loua RT, Bencherif H, Mbatha N, Bègue N, Hauchecorne A, Bamba Z, Sivakumar V. 2019. Study on Temporal Variations of Surface Temperature and Rainfall at Conakry Airport, Guinea: 1960-2016. Climate. 7(7):93. doi:10.3390/cli7070093.

Mall RK, Singh R, Gupta A, Srinivasan G, Rathore LS. 2006. Impact of Climate Change on Indian Agriculture: A Review. Clim Change. 78(2-4):445-478. doi:10.1007/s10584005-9042-x.

Marshall E, Aillery M, Malcolm S, Williams R. 2015. Agricultural Production under Climate Change: The Potential Impacts of Shifting Regional Water Balances in the United States. Am J Agric Econ. 97(2):568-588. doi:10.1093/ajae/aau122.

Matthew OJ, Abiodun BJ, Salami AT. 2015. Modelling the impacts of climate variability on crop yields in Nigeria: performance evaluation of RegCM3-GLAM system. Meteorol Appl. 22(2):198-212. doi:10.1002/met.1443.

Molua EL. 2009. An empirical assessment of the impact of climate change on smallholder agriculture in Cameroon. Glob Planet Change. 67(3-4):205-208. doi:10.1016/j.gloplacha.2009.02.006.

Müller C, Robertson RD. 2014. Projecting future crop productivity for global economic modeling. Agric Econ. 45(1):37-50. doi:10.1111/agec.12088.

Nimbrayan PK, Bhatia JK, Heena, Sunita. 2019. Growth and Instability in Area, Production and Productivity of Barley in Haryana vis-à-vis India. Curr J Appl Sci Technol. 35(6): 1-8. doi:10.9734/cjast/2019/v35i630210.

Ochieng J, Kirimi L, Makau J. 2017. Adapting to climate variability and change in rural Kenya: farmer perceptions, strategies and climate trends: Justus Ochieng, Joyce Makau and Lilian Kirimi / Natural Resources Forum. Nat Resour Forum. 41(4):195208. doi:10.1111/1477-8947.12111.

Panda A, Sahu N. 2019. Trend analysis of seasonal rainfall and temperature pattern in Kalahandi, Bolangir and Koraput districts of Odisha, India. Atmospheric Sci Lett. 20(10). doi:10.1002/asl.932. https://onlinelibrary.wiley.com/doi/abs/10.1002/asl.932. 
Panda A, Sahu N, Behera S, Sayama T, Sahu L, Avtar R, Singh RB, Yamada M. 2019. Impact of Climate Variability on Crop Yield in Kalahandi, Bolangir, and Koraput Districts of Odisha, India. Climate. 7(11):126-137. doi:10.3390/cli7110126.

Patel SK, Verma P, Shankar Singh G. 2019. Agricultural growth and land use land cover change in peri-urban India. Environ Monit Assess. 191(9):600. doi:10.1007/s10661019-7736-1.

Praveen B, Sharma P. 2019. A review of literature on climate change and its impacts on agriculture productivity. J Public Aff. 19(4). doi:10.1002/pa.1960. https://onlinelibrary.wiley.com/doi/abs/10.1002/pa.1960.

Rai CK, Arti A. 2017. Growth Rate of Area, Production and Productivity of Sugarcane Crop in Uttar Pradesh. Res J Agric Sci. 8(2):423-425. doi:3902-1311-2016-093.

Rani CR, Vanaja M, Bali SK. 2011. Climate change and rainfed agriculture: rural development perspectives. J Rural Dev. 30(4):9.

Rawat PK. 2012. Impacts of climate change and hydrological hazards on monsoon crop patterns in the Lesser Himalaya: A watershed based study. Int J Disaster Risk Sci. 3(2):98-112. doi:10.1007/s13753-012-0010-6.

Rolim J, Teixeira JL, Catalão J, Shahidian S. 2017. The impacts of climate change on irrigated agriculture in Southern Portugal. Irrig Drain. 66(1):3-18. doi:10.1002/ird.1996.

Rowan TSC, Maier HR, Connor J, Dandy GC. 2011. An integrated dynamic modeling framework for investigating the impact of climate change and variability on irrigated agriculture. Water Resour Res. 47(7). doi:10.1029/2010WR010195. [accessed 2020 May 4]. http://doi.wiley.com/10.1029/2010WR010195.

Rowhani P, Lobell DB, Linderman M, Ramankutty N. 2011. Climate variability and crop production in Tanzania. Agric For Meteorol. 151(4):449-460. doi:10.1016/j.agrformet.2010.12.002.

Salim RA, Islam N. 2010. Exploring the impact of R\&D and climate change on agricultural productivity growth: the case of Western Australia. Aust J Agric Resour Econ. 54(4):561-582. doi:10.1111/j.1467-8489.2010.00514.x.

Shruthi G, Rao BD, Devi YL, Masih J. 2017. Analysis of Area, Production and Productivity of Groundnut Crop in Telangana. Agric Sci Dig - Res J. 37(2). doi:10.18805/asd.v37i2.7993. [accessed 2020 May 4]. http://arccjournals.com/journal/agricultural-science-digest/D-4531.

Sitarambabu V, Chowdary NA, Solmon RP. 2014. Trends, growth and variability of Bengal Gram in Andhra Pradesh. Int J Dev Res. 4(2):560-562.

Suman J, Singh H, Kumar Verma D, Patil P. 2018. Inter Year Yield Instability of Major Crops in Rajasthan Agriculture. Int J Curr Microbiol Appl Sci.(7):549-560. 
Sustainability, Agri, Food and Environmental Research, (ISSN: 0719-3726), 9(2), 2021: 311-328 http://dx.doi.org/10.7770/safer-V0N0-art2244

Yadav SB, Vasani MJ, Chaudhari NJ, Shitap M. 2018. Forecasting Yield of Major Crops in Different District of Middle Gujarat and North Gujarat Using Statistical Techniques. Int J Curr Microbiol Appl Sci. 7(11):2202-2210. doi:10.20546/ijcmas.2018.711.246.

Yu C, Huang X, Chen H, Huang G, Ni S, Wright JS, Hall J, Ciais P, Zhang J, Xiao Y, et al. 2018. Assessing the Impacts of Extreme Agricultural Droughts in China Under Climate and Socioeconomic Changes. Earths Future. 6(5):689-703. doi:10.1002/2017EF000768.

Abbreviations: IPCC - Intergovernmental Panel on Climate Change, IITM - Indian Institute of Tropical Meteorology, IARI - Indian Agricultural Research Institute, MI - Monsoon Index

Received: $25^{\text {th }}$ June 2020; Accepted: $22^{\text {th }}$ November 2020;

First distribution: $07^{\text {th }}$ January 2021. 